\title{
FACTORS INFLUENCING HAPPINESS AMONG UNIVERSITY STUDENTS
}

In Happiness And Contemporary Society : Conference Proceedings Volume (Lviv, March, 20-21, 2021). Lviv: SPOLOM, 2021. P. 77-81. https://doi.org/10.31108/7.2021.15

ISBN 978-966-919-697-2 
https://doi.org/10.31108/7.2021.15

\author{
ÇOLLAKU Manjola \\ PhD, Mediteranean University of Albania (Tirana, Albania) \\ ÇAUSHAJ Romina \\ Msc, Mediteranean University of Albania (Tirana, Albania)
}

\title{
FACTORS INFLUENCING HAPPINESS AMONG UNIVERSITY STUDENTS
}

The Several studies have shown that happy individuals are successful across multiple life domains including friendship, income, marriage, work performance, and health. This paper explores factors in determining happiness among university students. Some of the variables or factors that have correlation with increasing the happiness of the university students are discussed in this paper. It is important to notice these factors, since, if we identify them, we will be able to deal with the improvement of happiness using accurate planning. The results can be used by students themselves and as a starting point for university policies which aim to raise the level of happiness among students.

KEYWORDS: happiness, university students, education, factors

\section{Happiness}

The attention in the topic of happiness has been present in every culture (Lyubomirsky, 2006) and recently, this interest has grown considerably. According to the World Health Organization health is a state that involves mental wellbeing (along with physical and social) that can be promoted by happiness. The concept of happiness has been associated with well-being, jubilation, pleasure and satisfaction (Seligman, 2002). We function better when we are happy; we are more energetic, more successful, healthier, more sociable, more creative, and longer-lived. Traditionally, wealth and richness were believed to be the source of happiness (Drakopoulus, 2007; Hill, 2004; Oswald, 1997). Happiness is commonly associated with an emotional state of feeling good (Layard, 2002; Vermunt et al., 1989). In psychology happiness has recently become an object of study, but there are many researchers interested in the subject (Argyle, 1997; Seligman, 2002; Lyubomirsky, 2008).

Education and happiness

Recently, happiness has gained increasing attention in the academic literature (Compton, 2005).

Education plays a significant role on many important aspects of people's lives. Higher education institutions often focus their attention to academic engagement and achievement, but it is essential that universities also focus on the health of their students. Education plays a particular role in influencing happiness in students, consequently there is a need for a more developed understanding of happiness in higher education.

The happiness of students is an important matter considering that university years are formative for students and can lead to lifestyles that endure for the years ahead. An examination regarding "happiness" particularly about the most significant groups of the society, the university students, appears very important. 
The joys and happiness students experience while in school greatly influence on what and who will they be as professionals.

According to Hoggard (2005) and Martin (2005), If students enjoy sufficient happiness in their student career, they are more successful in all aspects of education and are even happier in their job post-graduation. Happiness is often considered an essential criterion of a successful life and a psychological state that is continuously pursued in the life process.

Moreover, Astin (1997) argues that university years have strong effects on students and that the experiences students live through help them develop a greater sense of interpersonal and intellectual competence and a greater commitment to developing a meaningful philosophy of life.

According to Baker et al. (1999) schools can influence students' positive adjustment, and they have to work on building a psychologically healthy environment to support people's development in this context. Kern et al., emphasized that "schools need to consider how to build best and support students' well-being".

University contributes to students' positive adjustment when they function as psychologically healthy environments for development. Therefore, the question posed is does education influence happiness and if so, in what ways and how much?

Factors determining happiness among university students

Happiness is seemed to be influenced by various short-term and long-term variables (Alshehri et al. 2016), what happens during university years? Worldwide, university students face significant emotional, mental, physical, and social challenges during their school years (Mahmoud. Et. Al., 2012; Yorgason., et. Al. 2008). A student's ability to deal effectively with such challenges can influence whether a student will have positive or negative experiences as a result. Indeed there is no absolute standard of happiness, understanding the factors involved in these various challenges can help students toward positive and constructive life experiences.

Research shows that happiness is related to better social relationships (Diener and Seligman 2002), lower suicide rates (Bray and Gunnell 2006, healthier diet (Blanchflower et al. 2013), low risk of mortality (Chida and Steptoe 2008), and superior mental and physical health (Lyubomirsky et al. 2005).

According to Kim (2015), the perception of happiness among university students varies depending on individual backgrounds and subjective dispositions, measures to improve happiness with various activities are needed.

No link was found between happiness and the faculties (Gokler., et. Al., 2015). Pretorius and Blaauw (2014) and Yolande van Zyl and Manilall Dhurup (2018) found no connection between self-efficacy by gender or age did and happiness among university students.

There are few studies investigating the association between happiness and academic performance (Bukhari and Khanam 2017; Cheng and Furnham 2002; Matuliauskaite and Zemeckyte 2011; Önder, 2020).

It is common that students who have to stay up late and have less sleep feel unhappy (Choi et al. 2019; Gobinath and Jothimani 2020; Kitazawa, 2019; Shen et al. 2018; Thus Tan et al. 2020; Warner et al. 2008). 
Regarding gender influence on happiness, studies seem contradictory. Doğan and Totan, 2013 and Önder, 2020 didn't find out any significant predictor of happiness according to several studies. However, gender was found as a significant predictor of subjective happiness in a study by Lee et al. (2015).

Bukhari and Khanam (2017) and Bücker et al. (2018), found that happiness and life satisfaction is significantly positively correlated with academic performance.

According to Kuykendall, Tay, \& Ng, 2015, leisure is conducive to our happiness.

Good health of family members also contributes to the happiness of the

students (Argyle, 1997). Social participation has a direct impact on student's happiness (Phillips, 1967). The result from different studies suggests that college students' sustainable behavior was

positively associated with study engagement with happiness (Chambel and Curral, 2005; Choi, 2016; Corral-Verdugo et al., 2011).

Hoggard (2005) and Martin (2005) reported no meaningful correlation between

age and happiness. Positive relationship was found between students' GPA's and happiness levels (Demirbatir, 2013; Gilman et al. 2006). While, other studies indicated that happiness was not related to academic performance (Lyubomirsky et al., 2005; Okun et al., 2009).

Empirical studies show that one good source of describing happiness is volunteer works (Frey, 2008; Borgonovi, 2008; Abecia et al 2014)

Akhter (2015), Mahmoodi and Nadrian (2019), and Perez (2012) in their respective studies found that the level of happiness was higher among male students.

Abolmaali et al. (2014) and Mahmoodi and Nadrian (2019) reported that interes in his/her own field of study tends to develop his/her knowledge, positive emotions, and personal value. It is therefore likely for such a student to have a high level of happiness. Michalos (2008) and Mahmoodi and Nadrian (2019) reported that the academic year of education can predict happiness among students.

Mahmoodi and Nadrian (2019) and King et al. (2014) studies showed associations between high level of stress and low level of happiness among college students

Previous studies have shown that the students who are engaged in leisure activities, seek social connections, and have emotional relationships with others can reduce or manage their stress and improve their level of happiness (Chao, 2011; Merianos et al., 2012).

Studying more about factors that influence happiness among students would be very beneficial to a university and its students.

\section{REFERENCES}

1. Abolmaali, K., Ghafari, T. and Ajilchi, B. (2014) 'The prediction of high school girls' happiness based on their educational major and their mothers' gender stereotypes', Advances in Applied Sociology, Vol. 4, No. 4, pp.121-127.

2. Akhter, S. (2015) 'Psychological well-being in student of gender difference', The International Journal of Indian Psychology, Vol. 2, No. 4, pp.153-161.

3. Alshehri AA, Althobaiti SM, Alsaadi HD, Alnemari AK, Alyami H, Alyami M, Alswat KA. (2016) Subjective happiness assessment among Taif university medical students. Am J Educ Res. 4:111-114 
4. Argyle, M. (1997). Is happiness a cause of health?. Psychology and Health,12(6), 769-781.

5. Astin, A. W., Astin, H. S., Lindholm, J. A., Bryant, A. N., Szelényi, K., \& Calderone, S. (2005). The spiritual life of college students: A national study of college students' search for meaning and purpose. Los Angeles, CA: UCLA Higher Education Research Institute.

6. Astin, A. W., Astin, H. S., Lindholm, J. A., Bryant, A. N., Szelényi, K., \& Calderone, S. (2005). The spiritual life of college students: A national study of college students' search for meaning and purpose. Los Angeles, CA: UCLA Higher Education Research Institute.

7. Borgonovi, F. (2008). Doing well by doing good. The relationship between formal volunteering and self-reported health and happiness. Social science \& medicine,66(11), 2321-2334.

8. Bray I, Gunnell D. 2006. Suicide rates, life satisfaction and happiness as markers for population mental health. Soc Psychiatry Psychiatr Epidemiol. 41:333-337.

9. Chao, R.C.L. (2011) 'Managing stress and maintaining well-being: social support, problem-focused coping, and avoidant coping', Journal of Counseling and Development, Vol. 89, No. 3, pp.338-348.

10. Chow, H. P. H. (2005). Life satisfaction among university students in a Canadian prairie city: A multivariate analysis. Social Indicators Research, 70, 139-150.

11. Compton WC, Hoffman E. 2019. Positive psychology: the science of happiness and flourishing. Thousand Oaks (CA): SAGE Publications.

12. Demirbatir E, Helvaci A, Yilmaz N, Gul G, Senol A, Bilgel N (2013). The Psychological Well-Being, Happiness and Life Satisfaction of Music Students. Psychol. 4(11 A):16-24. doi: 10.4236/psych.2013.411A004

13. Diener E, Seligman ME. 2002. Very happy people. Psychol Sci. 13(1):81-84

14. Dost, M.T. (2006). Subjective Well-Being among University Students. Hacettepe Universitesi Egitim Fak. Dergisi, 31:188-197.

15. Drakopoulos, S. A. (2007). The paradox of happiness: towards and alternative explanation. The Journal of Happiness Study, 9, 303-315.

16. Grace Chan, Paul W. Miller and MoonJoong Tcha. (2005), International Review of Economics Education, volume 4, issue 1 pp. 20-45. DOI: 10.1016/S14773880(15)30139-0

17. Hill, R. (2004). Happiness in Canada since World War II. Social Indicator Research, 65, 109-123.

18. Hoggard, L. (2005) How to be Happy: Lessons from Making Slough Happy, Random House, UK

19. Kern, M.L.; Waters, L.E.; Adler, A.; White, M.A. (2015). A multidimensional approach to measuring well-being in students: Application of the PERMA framework. J. Posit. Psychol., 10, 262-271

20. King, K.A., Vidourek, R.A., Merianous, A. and Singh, M. (2014) 'A study of stress, social support, and perceived happiness among college students', Journal of Happiness and Well-Being, Vol. 2, No. 2, pp.132-144

21. Kitazawa M, Yoshimura M, Murata M, Sato-Fujimoto Y, Hitokoto H, Mimura M, (2018) Associations between Problematic Internet Use and Psychiatric Symptoms 
among University Students in Japan. Psychiatry Clin Neurosci. ;72:531-9 Early View.

22. Layard, R. (2005). Happiness: Lessons from a new science. New York.

23. Lyubomirsky, S., Tkach, C., \& DiMatteo, M. R. (2006). What are the differences between happiness and self-esteem. Social Indicators Research, 78(3), 363-404.

24. Mahmoud JSR, Staten R. (2021) The relationship among young adult college students' depression, anxiety, stress, demographics, life satisfaction, and coping styles. Issues Ment Health Nurs;33(3):149-156. doi:10.3109/01612840.2011.632708

25. Merianos, A., King, K. and Vidourek, R. (2012) 'Does perceived social support play a role in body image satisfaction among college students?', Journal of Behavioral Health, Vol. 1, No. 3, pp.178-184.

26. Michalos, A. C. (2008). Education, happiness and wellbeing. Social Indicators Research, 87, 347-366. https://doi.org/10.1007/s11205-007-9144-0.

27. Moller, V. (1996). Life satisfaction and expectations for the future in sample of university students: A research note. South African Journal of Sociology, 27 (1), 109-125

28. Oswald, A. J. (1997). Happiness and economic performance. England.

29. Paolini, L., Yanez, A. P. \& Kelly, W. E. (2006). An examination of worry and life satisfaction among college students. Individual Differences Research, 4 (5), 331-339

30. Perez, J.A. (2012) 'Gender difference in psychological well-being among Filipino college student samples', International Journal of Humanities and Social Science, Vol. 13, No. 2, pp.84-93.

31. Universal Journal of Educational Research 4(3): 622-631, 2016 http://www.hrpub.org DOI: 10.13189/ujer.2016.040322 The Relationship between Leisure Satisfaction and Happiness among College Students Sabri Kaya

32. Vermunt, R., E. Spaans and F. Zorge: 1989, 'Satisfaction, happiness and well-being of Dutch students', Social Indicators Research 21, pp. 1-33. 